\title{
The Contribution of Appearance to Women in the Labor Market
}

\section{A Contribuição da Aparência para a Mulher no Mercado de Trabalho}

\author{
Marielle Pistorello Graduada em Administração. Universidade de Caxias do Sul (UCS) - Brasil. \\ https://orcid.org/0000-0002-4376-2115 marielle.pistorello@hotmail.com \\ Vandoir Welchen Doutorando em Administração. Mestre em Administração. Universidade de Caxias do Sul (UCS) \\ https://orcid.org/0000-0001-7042-1239 - Brasil. vwelchen@ucs.br \\ Juliana Matte Doutoranda em Administração. Mestre em Administração. Universidade de Caxias do Sul (UCS) \\ https://orcid.org/0000-0003-0945-2479 - Brasil. Ju.cxs1@gmail.com \\ Daniel Hank Miri Mestre em Administração. Universidade de Caxias do Sul (UCS) - Brasil. dhmiri@ucs.br \\ https://orcid.org/0000-0002-0765-6868 \\ Cassiane Chais Doutora em Administração. Universidade de Caxias do Sul (UCS) - Brasil. cassichais@gmail.com \\ https://orcid.org/0000-0002-1922-9273 \\ Paula Patricia Ganzer Pós-Doutora em Administração. Instituto Federal do Rio Grande do Sul (IFRS). \\ https://orcid.org/0000-0003-4006-6517 paula.ganzer@gmail.com \\ Pelayo Munhoz Olea Pós-Doutor em Gestão Ambiental. Doutor em Administração. Universidade Federal de Rio \\ https://orcid.org/0000-0003-2183-8112 \\ Grande (FURG) - Brasil. pelayo.olea@gmail.com
}

\begin{abstract}
Appearance is an aspect that contributes to the professional development of people, considered a competitive factor in the labor market and an essential requirement in building successful careers. Women who work in executive positions can be responsible for decision-making in companies, such as hiring and promoting professionals, two moments in which appearance assumes an important role. They are also professionals whose positions tend to require significant care with the personal image. Therefore, the objective of this study was to investigate the contribution of appearance to women in the labor market by analysing female executives of a class council in southern Brazil. Through a generic qualitative study, five executives were interviewed. As a result, good appearance is related to adequacy, way of dressing, hygiene care, and communication skills. Besides, appearance is necessary to build a credibility image in the labor market, and it interferes, in a pleasing way, both in job interviews and in the promotion of professionals.
\end{abstract}

Keywords: Appearance. Beauty. Labor Market. Executive Women. Generic Qualitative Study.

\section{RESUMO}

A aparência é um aspecto que contribui para o desenvolvimento profissional das pessoas, considerado um fator competitivo no mercado de trabalho e um requisito essencial para a construção de carreiras bemsucedidas. As mulheres que trabalham em cargos executivos podem ser responsáveis pela tomada de decisões nas empresas, como a contratação e a promoção de profissionais, dois momentos em que a aparência assume um papel importante. São também profissionais cuja posição tende a exigir um cuidado significativo com a imagem pessoal. Portanto, o objetivo deste estudo foi investigar a contribuição da aparência para as mulheres no mercado de trabalho das executivas de um conselho de classe no sul do Brasil. Através de um estudo qualitativo genérico, cinco executivas foram entrevistadas. Como resultado, a boa aparência está relacionada à adequação, vestimenta, cuidados com a higiene e habilidades de comunicação. Além disso, a aparência é necessária para construir uma imagem de credibilidade no mercado de trabalho e interfere, de forma agradável, tanto nas entrevistas de trabalho quanto na promoção dos profissionais.

Palavras-chave: Aparência. Beleza. Mercado de trabalho. Mulheres executivas. Estudo Qualitativo Genérico. 


\section{INTRODUCTION}

The concern with appearance has followed the human being since the Ancient Age, and, over time, this concern has taken on new forms. Studies have shown that appearance can significantly impact people's attitudes and mentality, as beauty is often related to intelligence and success (HAMERMESH, 2011; HAKIM, 2011). All people can perceive beauty, even those who claim to have no concern for appearance will feel the need to think about it on some occasions throughout their lives (MARWICK, 2004).

Besides being a matter of adequacy, maintaining a good appearance is also a way of manifesting beauty (HAMERMESH, 2011), considered essential to human beings, and defined by Dweck (2006) as the maximum expression of personal appearance. Economists found that appearance is a relevant economic factor in the labor market, as people considered attractive are also considered more reliable (WILSON; ECKEL, 2006) more likely to be hired in job interviews (ROOTH, 2009), considered more competent by their employers (MOBIUS; ROSENBLAT, 2006), and also have better wages (HAMERMESH, 2011).

Hamermesh (2011) and Hakim (2011) published researches about appearance and their reflections in the labor market, which support, with different approaches, the same thesis: both in personal and professional life, beautiful people obtain quantifiable economic advantages. Even in jobs in which appearance should not matter, it does. Frieze, Olson, and Russel (1991) found that handsome men had higher initial wages and faster growth in the first ten years of their career. For women, although appearance had little effect on initial wages, it did influence the increase in earnings over time. Wong and Penner (2016) presented the same results: people rated as more attractive had salaries about $20 \%$ higher than people classified as less attractive.

Competitiveness in the labor market requires, especially for women, meeting all demands, even subjective ones such as beauty. According to Ramos (2012), the wages paid to women are still lower than those received by men, which means earning good wages is even more difficult for women. Hamermesh (2011) stated that appearance has a more significant impact on women's earnings than men: more beautiful women earn $8 \%$ more than the average, while men considered more attractive earn $4 \%$ more.

Betiol and Tonelli (1991) and Bruschini (2007) point to women's progress in the labor market in predominantly male job positions. The participation of women in these jobs has become not only an economic necessity but the result of a change in women's profile, who have started to seek personal satisfaction and the reinvention of their role in society (BETIOL; TONELLI, 1991). In contrast to the beginning of the 20th century, 21st-century women, who take care of their appearance, are more successful (HAKIM, 2011). According to the sociologists Wong and Penner (2016), women who spend more time and money to care for their appearances, such as hairdressers, manicures, and makeup, stand out more than women who do not keep these aesthetic habits.

Sant'Anna (2014) pointed to the twentieth century as the era of beauty, especially from the 1950s, when beautification became necessary. In Brazil, this need is one of the economy's biggest drivers nowadays. Łopaciuk and Łoboda (2013) referred to Brazil as one of the world's engines of the beauty industry, which consistently demonstrates high efficiency in beauty consumption, presenting one of the most recent growths in the world when it comes to this market. To have an idea, according to the Brazilian Association of Personal Hygiene, Perfumery and Cosmetics Industry (ABIHPEC, 2017), Brazil was the fourth global market in beauty, behind the United States, China, and Japan. Brazilians spend 1.5\% of their budget on hygiene and beauty products, having handled $\$ 42.6$ billion in 2016. These investments can be justified, among other factors, by people's need to build a credibility image in the society and the labor market.

The choice of this research topic is related to the intention of understanding whether the proposed theory can be observed, in fact, within an executive women class council. Furthermore, the relevance of the research is supported by the need for theoretical contributions regarding the topic (SIERMINSKA, 2015). Reflecting on such considerations, on the appearance, how people perceive it, and its repercussion in the professional field, it is possible to identify that it can be an essential resource, not only for professional advancement but as an advantage in job interviews, when the first impression is determinant (ROOTH, 2009; SANTOS, 2016). 
Thus, this research's objective was to investigate the contribution of appearance to women in the labor market, according to female executives of a class council, from a city in southern Brazil. A generic qualitative study was carried out and described women at the executive level. We sought to understand how appearance is perceived, in the professional field, by executive women of the Council; in addition to identifying whether interferences, based on appearance, occur in the promotion of professionals in the sector under study and assessing whether appearance can favor a candidate, in a job interview, in the investigated business context.

\section{THEORETICAL BACKGROUND}

\subsection{Women and the Labor Market}

In the past, women were born and educated to take care of the family, the house, and food. During the 19th century, some women, from less favored classes, were employed in textile factories, with children and adolescents, as a way of cheap labor, subjected to workloads, apparently contenting themselves with their condition as workers (NOGUEIRA, 2004). Female work was little valued, and many of these women still performed extra activities at home (CALIL, 2000).

Capitalism is a milestone in the separation between the domestic environment and the labor market. The family went from being a production unit to becoming a consumption unit, and women responsible for its administration (COSTA, 1984). The actual introduction of women into the labor market took place with the First and Second World Wars, when men went to war and women started to assume not only the role of wife and mother but the family business and the position of men in the labor market (LEONE; BALTAR, 2006).

In Brazil, only from the second half of the 1980s, according to Bruschini and Lombardi (2002), the growth of female activity in the labor market occurred, and also a change in women's profile which, later on, had access to new opportunities, including admission to universities. Bruschini (2007) points to women's evident progress in the labor market, especially in traditionally male fields, such as medicine, Law, Architecture, and Engineering.

According to the World Bank, Brazil has already made considerable progress and has a better environment than the average for Latin America and the Caribbean in terms of difficulties and challenges for women in the labor market, but is still well below the average for the Organization for Economic Cooperation and Development countries (OECD). More than $50 \%$ of the Brazilian population are women, and $43 \%$ of the workforce comprises women. However, women only occupy $37.8 \%$ of management positions. Nevertheless, even when more qualified than men, women's salary is equivalent to $25 \%$ less (WORLD BANK, 2018). This differentiation in income does not change, even though the average female enrollment is higher than men in Brazil (IBGE, 2017).

Similarly, Gipson et al. (2017) found that, despite the lack of a significant difference in style and performance between men and women in leadership positions, prejudice against women in selection and access to development opportunities are clear and remain a problem. For Sousa and Guedes (2016), although the increase in the participation of women in the Brazilian labor market is visible, such an advance has not been able to equalize the gender division of labor in the country. For example, although they occur at all levels of education, income differences are more significant in higher education, where women represent more than half of the population with this level of education.

Besides, there is still greater difficulty raising women to leadership positions (LEONE; BALTAR, 2006). Rocha-Coutinho (2004) points out that, although the barriers imposed on women are sometimes due to traditional gender stereotypes, one can mention the difficulty women still face in reconciling careers and family. This scenario means that some women do not aspire to leadership positions since they are often unwilling to give up their family and personal well-being in favor of professional advancement. Finally, Hakim (2011) states that we cannot ignore the importance of education, qualification, intelligence, and experience for professional success, but taking care of appearance can mean a competitive advantage in the labor market. 
Therefore, by turning this discriminatory factor into a competitive advantage, women can increase professional success chances.

In Brazil, it is still possible to observe the discrimination and the limitation that predominates throughout the women's career, which shows the ineffectiveness of the current judiciary power in ensuring equal opportunities among genders in the Brazilian labor market (ROQUE; BERTOLIN, 2021). Women's position in the labor market still has challenges to be overcome to equalize the genders (FERNANDES et al., 2019). For example, Dzubinski, Diehl, and Taylor (2019) mentioned that executive women must exercise strong gender self-control to break the glass ceiling in organizational leadership contexts with intensely masculine norms.

\subsection{Beauty and Appearance}

The fascination caused by beauty is part of human history and the favoring it attracts, especially for women. The power of beauty is undeniable (DUBAY, 1999). However, the aesthetic standards are not eternal; they vary in time and space and from one region to another. Climate, religious beliefs, historical factors, political regimes, and economic systems can influence such differences (KURY; HARGREAVES; VALENÇA, 2000). Marwick (2004) says that, despite small variations, the perception of beauty in the Western has changed very little since antiquity and that beauty has always been valued.

For Mahajan (2007), society is obsessed with beauty, so both men and women, recognizing the value of a good appearance, continually strive to improve it. Nevertheless, according to Bourdieu (2001), appearance has, for women, a different relevance than it does for men, and, therefore, they invest much more time, money, and energy with their presentation. Hamermesh (2011) differentiates the concepts of beauty and appearance, stating that beauty is a genetic characteristic, natural to those who have it. However, a pleasant appearance is something that anyone can achieve through clothing, hair care, and even with an adequate diet.

For Hamermesh (2011), lousy appearance is not a crucial disadvantage, but it is something that, with some effort, can be overcome. Such statements indicate that all people can build a good appearance since it is not only related to beauty. Similarly, Mahajan (2007) had already stated that, in addition to facial characteristics, society measures appearance in variables such as: dressing up, dressing well, and even making use of cosmetics. In early interactions between individuals, appearance often causes judgment and comparison. Not only does a person's appearance tend to overshadow other characteristics, forming the basis of first impressions, but it also influences people's perception of the person's attributes (GRAHAM; HARVEY; PURI, 2017).

\subsubsection{Halo Effect}

Physical appearance is a factor that can play an essential role in people's judgment. Thorndike (1920) created the term "halo effect," which refers to human beings' tendency to classify people based on first impressions. In his research, the psychologist concluded that after creating a first global impression about a person, the tendency is that the characteristics captured, later, about that person, will confirm that first impression.

Wilson and Eckel (2006) analyzed the effects of appearance on people's perception of reliability. In their study, they suggest whether or not people trust unknown people based on their appearance. Sorcher and Brant (2002) evidenced the influence of the halo effect in the business world. The study approached that presidents and executives, and other high-level positions in companies decide to hire job candidates based on a first impression. Besides, Kahneman (2011) believed that first impressions are also important in professional development when combined with the performance factor.

Standing (2004) explained the halo effect, commonly known as "the stereotype of physical attractiveness," or the principle "what is beautiful is good," as a human tendency to favor beautiful people, associating them with a positive personality. Schneider, Gruman, and Coutts (2012) proposed that, at work, the halo effect is also manifested in employees' performance evaluations by their managers. For the author, the phenomenon is the most common bias in performance evaluations. 
According to Wilson and Eckel (2006), people use physical attractiveness as a shortcut in forming an opinion about an individual's reliability and performance. Although this cooperation increases job performance, the effect of beauty disappears, according to Andreoni and Petrie (2008), when information about the employee's real work performance is revealed.

\subsubsection{Beauty Premium}

Research has shown that people with a better appearance tend to be more successful (BIDDLE; HAMERMESH, 1998; MOBIUS; ROSENBLAT, 2006). This reward is called a "beauty award," or beauty premium. Mobius and Rosenblat (2006) research found that $4 / 5$ of the effect of beauty on people refers to physical characteristics, while $1 / 5$ is because the most attractive people are more confident, another benefit of beauty. Besides, about $15 \%$ to $20 \%$ of the beauty prize results from self-confidence, while oral communication and appearance contribute about $40 \%$.

Sierminska (2015) addressed the beauty award from a different perspective, stating a salary reward involving appearance, which is more significant in jobs where a productive resource is plausible. According to Sierminska's research, a grand prize exists in jobs that require substantial amounts of interpersonal interaction, but such a prize could not be identified in jobs that deal only with information and data analysis.

In the research by Bóo, Rossi, and Urzúa (2013) on beauty-related awards, the existence of beauty premium was evidenced in the initial job search stages. The study identified that beautiful people receive $36 \%$ more feedback than unattractive people and suggest that beautiful people include photos in their resumes, increasing the possibility of interviews by around $30 \%$. Besides, the survey recognizes that, in occupations that require interaction with customers, administrative and service areas in general, the existence of a beauty premium is even more relevant.

\subsection{Relationship between Executive Women and Appearance}

Hewlett (2014) questioned executives what was most important in executive presence. After ethics and communication skills, appearance was identified as one of the essential aspects. The importance given to appearance was highlighted in the research by Habermann-Horstmeier (2007), which is more important for women who want to achieve a leadership position than for men, and related this aspect to vitality, high performance, and success. However, she treated the topic with concern, since these women may become mentally disturbed and expect too much from themselves and develop psychosomatic stress disorders, with the concern of maintaining their appearance (HABERMANN-HORSTMEIER, 2007).

Betiol and Tonelli (1991), analyzing the executive woman in the labor market, affirm that dressing well is an external indicator of positivity and that many executives associate professional success with a good appearance. In dressing, sloppiness can indicate a person's carelessness, internal disorganization, lack of confidence, and self-esteem. The authors state that, in addition to professional training, intellectual competence, and work capacity, it is also necessary to invest in appearance, as physical appearance and dressing are indicators of the individual's degree of disposition.

According to Grzybovski, Boscarin, and Migott (2002), a good appearance is one of the human resources most required by executives. Barros Neto (2005) argues that some people are distinguished from others by personal characteristics that make them natural leaders and cite a physical appearance as one of these characteristics. Hakim (2011) states that appearance makes a difference even at the top of the business pyramid.

Estevão-Rezende, Nascimento, and Alves (2018) identified that labor relations in the events industry are guided by physical and aesthetic criteria that do not necessarily involve the professional qualification and competence of the selected casting. This perception that appearance and/or aesthetic standards influence the job market can lead to consumption focused on the body (beauty treatments, fashion, surgery), as it represents a symbolic and material way of positioning oneself within societies. Additionally, it can also become a way of 
relating to the world - becoming visible, recognized as valuable, and favorably regarded as any other citizen (GORDON, 2019).

Although beauty and appearance concepts are different (HAMERMESH, 2011), they are sometimes treated as synonyms (MAHAJAN, 2007) and may also assume other terminologies, such as physical appearance (GRZYBOVSKI; BOSCARIN; MIGOTT, 2002), good looks (WONG; PENNER, 2016), personal appearance (DWECK, 2006) and attractiveness (TALAMAS; MAVOR; PERRETT, 2016). This research adopted the term appearance to refer to these concepts.

\section{METHODOLOGICAL PROCEDURES}

This study is characterized by qualitative approach research, exploratory and descriptive objective, and generic qualitative study strategy (PERCY; KOSTERE; KOSTERE, 2015). This research used primary data, interviews and non-participating observations, and secondary data, such as the previously discussed theoretical background.

The research was carried out at the Council of Businesswoman of CIC of Caxias do Sul, a non-profit class council that brings together legal entities active in business from the northeast region of the state of Rio Grande do Sul, Brazil. The Council has as members approximately one thousand legal entities of micro, small, medium, and large size, representing the segment of industry, commerce, and services. Founded on July 8th, 1901 , the entity belongs to the civil class, and is one of the largest class entities in the south of the country and it is considered the oldest and most substantial business entity in the interior of Rio Grande do Sul (CIC, 2021).

$\mathrm{CIC}$ brings together more than 20 employers'unions through its members, representing around 25 thousand companies, which formally employ over 160 thousand workers and generate a GDP of approximately R\$21 billion (FEDERASUL, 2016). Since its foundation, CIC's primary objective has been to act proactively, serve as a business community model, strengthen free enterprise, and undertake and compete. In addition to monthly and free attendance, the entity promotes different courses, designed according to the companies and the market needs (CIC, 2021).

The Council of Businesswoman of $\mathrm{ClC}$, which currently has the participation of 23 women, was founded on April 14th, 1997, created to increase female participation in the economic and community life of the city, encouraging the sharing of experiences among businesswomen. With focus on female entrepreneurship, the Council seeks to develop schedules of activities that contemplate the business community's interest (COUNCIL OF BUSINESSWOMAN OF CIC, 2017).

The women interviewed were chosen to participate in the study because of their hierarchical level, having been selected only female executives or acting at the board level, in order to meet the proposed objectives. The proposal of this research was exposed to the counselors on July 24th, 2019, in the weekly council meeting. Among the twenty-three women who are members of the Council, five were willing to participate in the study.

Data collection was carried out through semi-structured interviews, and non-participant observation since the interview leads the researcher to the observation, while the observations can suggest the necessary depths for the interviews (FLICK, 2018a). The script used for the interviews was prepared based on the theoretical framework, bringing together the themes and key elements highlighted in Table 1. The interview script used in this study was adapted from Gomes (2010) research, and the protocol for non-participant observation used was built based on Bencke (2016) research. The interviews were conducted from August 29th, 2019, to September 14th, 2019, in the workplaces of the women interviewed, which allowed them to act naturally and eliminated traces of shyness, reducing the risks of bias in the results guaranteeing better perceptions for observation. 
Table 1 - Themes and key elements of the interview script

\begin{tabular}{|c|c|}
\hline THEMES & KEY ELEMENTS \\
\hline Personal data & $\begin{array}{l}\text { - Age, place of birth, marital status, education. } \\
\text { - Profession, the company you work in, how long have you been in this company, } \\
\text { and how you did you get to your position? }\end{array}$ \\
\hline $\begin{array}{l}\text { Role / Meaning of } \\
\text { appearance }\end{array}$ & $\begin{array}{l}\text { - Talk about the role of appearance in the lives of executive women and your life. } \\
\text { - How do you define, and what does looking mean for you? } \\
\text { - Do you consider that the concept of good looks changes over time? Has that } \\
\text { concept changed for you? } \\
\text { - If you could advise a professional at the beginning of her career about } \\
\text { appearance, what advice would you give? }\end{array}$ \\
\hline Stereotypes & $\begin{array}{l}\text { - Is there a woman you admire professionally /? If so, mention the reasons. } \\
\text { - Do you identify any patterns in the appearance of successful women? } \\
\text { - Among the women you live with, how do you perceive appearance? What are the } \\
\text { characteristics in common among them, regarding the appearance? } \\
\text { - Do you consider that appearance can interfere in hiring / promoting a } \\
\text { professional? Comment. }\end{array}$ \\
\hline Habits & $\begin{array}{l}\text { - How do you enjoy your time outside the work environment? } \\
\text { - Do you have any habits when it comes to beauty and health care? Which and } \\
\text { why? } \\
\text { - How do you reconcile your personal presentation with your agenda? }\end{array}$ \\
\hline
\end{tabular}

Source: the authors (2020).

The interviews generated a total of 5 hours and 25 minutes of recordings. The interviews' content was transcribed for later content analysis, using the theoretical basis, aligned with the research objective and problem. The content analysis phases followed the recommendations of Bardin (2013): a) organization of the analysis; b) coding; c) categorization; d) treatment of results, inference, and interpretation of results. Content analysis was performed with the aid of the NVivo $12^{\circledR}$ software (FLICK, 2018a). It is noteworthy that the final categories that composed the data analysis emerged from the organization of the data in the software, during the study, as a posteriori category.

In providing quality to the qualitative research, validity and reliability criteria were adopted. The research validity is related to the confidence with which it is possible to draw conclusions based on its analysis, while reliability relates to the research procedures consistency on evaluating a phenomenon (FLICK, 2018b). One strategy to promote quality in research is triangulation (DENZIN; LINCOLN, 2018). In this research, triangulation occurred through the interviews' analysis and relationship and non-participant observation with the theoretical background.

\section{ANALYSIS AND DISCUSSION OF RESULTS}

\subsection{Personal and Professional Profile}

Initially, the interviews sought to outline the interviewees' personal and professional profiles: age between 35 and 55, married women, mothers, and businesswomen who work in different areas such as metallurgy, civil construction, fashion, international trade, and information technology (IT). Table 2 shows a summary of the interviewees' profiles. 
Table 2 - Interviewees' profile

\begin{tabular}{|l|l|l|l|l|l|l|}
\hline Interviewee & Age & Place of birth & $\begin{array}{l}\text { Marital } \\
\text { Status }\end{array}$ & Children & Business & Job position \\
\hline 11 & 40 & Caxias do Sul & Married & 2 & Metallurgy & Director \\
\hline 12 & 35 & Caxias do Sul & Married & 1 & Construction & Director \\
\hline 13 & 50 & Nova Pádua & Married & 1 & Fashion & Director \\
\hline 14 & 55 & Caxias do Sul & Married & 1 & International Trade & Director \\
\hline 15 & 35 & Caxias do Sul & Married & 1 & IT & Director \\
\hline
\end{tabular}

Source: the authors (2020).

When asked about their positions and professional trajectories, the interviewees expressed the need to manage different areas of their lives: work, family, and volunteering activities. They also commented on the woman's ability to take on these diverse roles and reconcile family and professional life. In opposition to the perspective of Rocha-Coutinho (2004), these women do not seem to see this as a difficulty, but as a competitive advantage for women, as described by 14 : "We are used to solving matters at home, at work [...] we are used to thinking about several areas at the same time during the day [...] we need to understand that we have this competitive advantage".

However, 12 and 13 agreed with the author when mentioning that having children interferes with women's professional career. 12 reported that she left motherhood for later, in favor of her career, while I3, similarly, talked about how motherhood happened in her life, in a late way: "I got pregnant at 40 , I had my son at 41 , and my pregnancy was a surprise pregnancy, it was not planned".

Despite the different trajectories in their professional careers, there was, among these women, evident security regarding their role in the labor market. The interviewees reached prestigious positions in their careers and, even those who inherited the management of family businesses, before reaching the position of directors, had to show themselves capable, many times, overcoming the predilection for the male figure in the direction of their companies, as stated by Gipson et al. (2017):

I used to question why my brother was already working at my father's company, and I had to graduate to work there while him, since he was 13 , already was? So, there was this questioning, and there was this chauvinist tendency from my father to want to pass the company on to his son, and not to his daughter [...]. So, at that moment, I visualized this tendency for the succession to be for the male son and not for the female daughter. And the position in which I find myself today, which is above my brother's position, I conquered it, I conquered it together with my father. Unquestionably he, at that first moment, did not believe me either (I1).

I have a brother a little younger than me, and I would say that my father's dream was for my brother to take over the company, but my brother has no profile and did not want to. He declaredly did not want to take over the company, which was left for me. So, at this point, I believe that if my brother had shown a little more interest in the family business, I would not have had this opportunity (I2).

This difficulty in ascending to leadership positions, which is even higher for women, is based on Leone and Baltar (2006). Concerning the differences between men and women in the labor market, there were also some occurrences in the professional career of these women that reaffirm the existence of such differentiations. Bruschini (2007) points to female activity growth in predominantly male areas, as happened to 11,14 , and 15 . However, these women's reports show that the female presence is not equal in their fields of activity.

12, for example, stated: "I work with civil construction ... I go to several sector meetings and, in general, I am the only woman among 15 to 20 men". Similarly, I5 reflected: "In my relations, I have many contacts with customers [...] There is a company in which my interlocutor is a woman, the rest are all male interlocutors". With this, it is possible to verify that some women experienced discriminatory situations without actually realizing them. Although 12 and 15 stated that they never felt any prejudice for being women, they admit that the sectors 
in which the interviewees operate are still predominantly male and that, sometimes, the treatment is differentiated, and even improved, because they are women. In these masculine environments, executive women must exercise strong gender self-control to break this discrimination barrier (DZUBINSKI; DIEHL; TAYLOR, 2019). Women's position still has challenges in the face of gender equality (FERNANDES et al., 2019).

Women who ensure that they have not suffered any kind of direct discrimination, or acknowledge that it exists and possibly goes unnoticed, or end up revealing during the interview that they experience discriminatory situations but abstain from them. "As a woman, I think I even have a different treatment, with more kindness. It is often unnecessary, because I think I should be treated as a colleague, and they treat me like a woman" (12). This is in line with Israelsson's vision of women's respectability in the labor market (ISRAELSSON, 2017).

\subsection{The Role and the Meaning of Appearance}

\subsubsection{The Role of Appearance in the Life of an Executive Woman}

When asked about the role of appearance in executive women's lives and their own lives, the interviewees claimed to be an essential factor, agreeing with the perception of Habermann-Horstmeier (2007). 12 said that appearance is essential for all people, in all areas, but that it plays an even more relevant role in the life of an executive woman:

More generally, I believe that appearance matters in anyone's life, not just the executive woman. Much in the life of the executive woman, indeed, but in the life of the executive man too. In any job in which you are, in any position, of any salary, the appearance makes the difference. It would be hypocrisy to say no (I2).

$11,13,14$, and 15 mentioned that the executive woman is the image of her own business and, therefore, carelessness with her appearances could prejudice them by transmitting the wrong message. "There must be consistency between what you want to transmit with what you show. If you do not have that consistency, you cannot reach your goals "(I4). Also, according to 14 , an executive's way of dressing is a form of communication, and the speech and appearance must match. A similar relationship of interaction, between interior and exterior, is addressed by Betiol and Tonelli (1991) when they affirm that the appearance reflects the person's interior and that a lousy appearance can denounce the lack of organization and disposition.

In the same sense, 12 mentions that "as a business owner, your company reflects what you are, a fact! You go into a messy place, you meet the owner, he is messy", and 14 stated that "appearance is very important, it is a construction, especially in my case as I take the name of the company."

\subsubsection{Definition of Good Appearance}

When asked to define good appearance, all interviewees used the term adequacy, synonymously used by Hamermesh (2011), when referring to what is appropriate. Other characteristics mentioned as essential parts in building a good appearance: posture, clothing, makeup, discretion, hygiene, communication, and tone of voice. Their points of view corroborate Mahajan's (2007) and Wong and Penner's (2016) definitions of what looks good (MAHAJAN, 2007; WONG; PENNER, 2016).

Supporting the definitions given by the interviewees, during the interviews, it was observed that all of them seemed to be concerned with their appearance since they were in good shape, were elegant in their dress, used discrete makeup, and communicated very well with security and eloquence. Table 3 provides a summary of the concepts elaborated by the interviewees about good appearance. 
Table 3 - Good-looking concepts according to the interviewees

\begin{tabular}{|l|l|}
\hline Interviewee & Definition of good appearance \\
\hline 11 & $\begin{array}{l}\text { It consists of good posture and fitness. The appearance must be following the interests of the woman. } \\
\text { Good appearance should generate a positive impact of a serious person, bringing him/her closer to the } \\
\text { respect he/she desires. }\end{array}$ \\
\hline 13 & $\begin{array}{l}\text { It means being adequate with what you expect from the labor market. Appearance must match the } \\
\text { expectation of being taken seriously or not. }\end{array}$ \\
\hline 14 & $\begin{array}{l}\text { It is adequacy, clean clothes, scented clothes, well-ironed clothes, good hygiene, well-kept teeth, wearing } \\
\text { makeup. A good appearance will never decrease someone. It will always add up. However, it must have } \\
\text { content: the appearance must match the speech; otherwise, it does not make sense. }\end{array}$ \\
\hline 15 & $\begin{array}{l}\text { It is a matter of adequacy, and it is the way to communicate, behave, dress, and discretion, not to be } \\
\text { distracted by exaggerations. It is a softer tone of voice. This set is also a way of making communication } \\
\text { more effective in business. }\end{array}$ \\
\hline & $\begin{array}{l}\text { It is adequacy, hygiene, not smoking, not biting nails, not wearing clothes that do not fit, or conveying a } \\
\text { wrong image, as clothing tells a lot about who we are, what we believe in, and how we position ourselves } \\
\text { for the labor market. It is the elegance in speaking, not speaking too loudly. It is feeling good and looking } \\
\text { like that. }\end{array}$ \\
\hline
\end{tabular}

Source: the authors (2020)

\subsubsection{Good Appearance Concept over Time}

The next question referred to the appearance concept over time. The interviewees talked about how their opinions about appearance changed over the years and with maturity. They all agreed that the concept of good appearance has changed over the years and through experience.

11 mentions her daughter's birth and joining the Council of Businesswoman as events that motivated her to be even more concerned with her appearance. 12 said that, during one of her professional experiences, as a teenager, she received feedback from her manager to improve the care with her appearance: "That day, I didn't like hearing that, I confess it was horrible [...] it was a milestone for me, it was bad at that time, but even today it stays in my head, that you really should dress according to what you expect, with what you intend to transmit to people". This testimony from 12 corroborates with Mahajan (2007) when stating that, once the value of good looks is recognized, people strive to improve it.

13 reported that the concern became greater after a professional experience in a bank, in which the appearance issue was highly demanded of the employees. 14 revealed that, over time, a lower level of rigidity had been established in her professional life concerning appearance:

I wanted people to see that I was okay so that I could pass on good things to them. [...] When I entered the bank, the bank gave me a uniform, I worked with a uniform, which was very important for me because I did not have suitable clothes to work in the bank [...]. Moreover, the bank paid for a 15-day course in Porto Alegre, so I could learn how to put on makeup, how to behave, how to look well, how to deal with the public [...] for me, it was a lesson. It was very good! It became an addiction that I still have (I3).

The concern has always existed, in the beginning, more, today less, because I have already internalized what the business environment wants and approves. It wants and approves in the sense of being taken seriously and that my communication is effective. So this is easier for me. I don't need that much rigidity. I allow myself to visit a customer with jeans and a shirt, which before, in the beginning, I did not. In my head, I had to wear a suit [...], but this is a matter of experience (14).

The recognition of changes in aesthetic patterns over time and space is an event supported by Marwick (2004) and Kury, Hargreaves, and Valença (2000). All interviewees had a specific occasion or event in their lives, which 12 referred to as a "watershed," a moment that led them to reflect more on the issue of appearance or from a different perspective. The feedback of a manager, the requirement of a company, the 
need to transmit greater credibility, adapt to their means, and even motherhood were situations that influenced these women's appearance standards.

\subsubsection{Appearance Advice for Young Professionals}

When the interviewees were asked to answer, what would be the advice, on the appearance, that they would give to a professional at the beginning of her career since women still have unfair disadvantages on the career advancement (LEONE; BALTAR, 2006; HABERMANN-HORSTMEIER, 2007; GIPSON et al., 2017). I1 stated that managers are always observing the small details and that appearance is a factor that builds credibility and does not go unnoticed:

[...] for a woman who wants to grow professionally, who wants to run for more notorious positions, she has to demonstrate that she cares, because the manager will always analyze this type of thing and women, like it or not, still have disadvantages over men. She will have to be more competent than him, she will have to be more knowledgeable than him, and I think that today the issue of appearance, posture adds up to many points for a choice if you are competing with a man. So, I think it is essential (I1).

12 and 14 commented that it is necessary to reflect on what appearance is conveying and whether it conveys the intended message, as expressed by 12 in advising "that this person should seek to fit in the best possible way, within her work, within what she desires, that she should not use the appearance against her, but that she should use the appearance in her favor. Transmitting the wrong message can slow down and even hinder professional development. In this regard, 14 stated:

[...] always look for a match between whom you communicate with, and whether you are effectively communicating with your appearance. Appearance is speech, gestures, clothes, hair. It's all; it's the way you behave. If you go to an environment and keep screaming, or if you speak more elegantly. So appearance is all of that together. Worry about it: getting to know the segment in which you want to work in, or which you alreay work in, how they are, how they speak, gesticulate, dress, and if that is what you want to succeed, [...] this is the most important thing, it looks like this, you have to understand and adapt to be successful. If you don't change and adapt, you will lose time, lose business, but you will learn this, you either learn it or will not be able to be as effective as you expect (I4).

\subsection{Stereotypes of Interviewees}

\subsubsection{Appearance Patterns}

We verified if the interviewees could identify, among the successful women they know, if there is some kind of pattern concerning appearance. The women interviewed showed a concern to present themselves well and look good, but 13 defended that each one can do it independently. There was a consensus among the interviewees that all successful women care about appearance; above all, they adapt to their environments:

The vast majority of executive women I know have a pattern, special care with this issue of aesthetics, posture, the way they dress, care for their bodies. I don't know anyone successful who doesn't take this care [...] each in their way (I1).

Yes, at CIC we have doctors, we have advisory women, like me, company directors, commerce, everything, event organizers ... I believe that the most successful women are more effective in this combination: of speech and appearance [...] including some women, in the beginning, as soon as they joined $\mathrm{CIC}$ here, they did not have this concern with appearance, now they have it. Because the environment ended up warning, they start to see 
one, two, ten, twenty times, and then they start, themselves (this is the testimony of women here), they see the need to adapt (14).

This perception of the interviewees that all successful women are concerned with appearance, considering themselves were successful women and notably concerned with appearance, is consistent with practice. Such an event is following the theory of Graham, Harvey, and Puri (2017), that there is a relationship between appearance and ascension to the CEO position. In addition to framing Hakim's (2011) and Hamermesh's (2011) theory, appearance influences professional success (HAKIM, 2011; HAMERMESH, 2011).

\subsubsection{Influence of Appearance on Hiring and Promoting Professionals}

When asked about the existence of appearance interferences in a job interview, all interviewees agreed that appearance is a determining factor at the time of selection. 11 said that even the appearance of candidates on social networks influences hiring in their company: "Today social media is also used for this, we look at what is posted, how the person is dressed on social media. All companies do this [...] many people end up not being hired because of social media". 15 reported: "[...] I have personally barred hiring, and gave preference to other people, due to the way the person behaved, was dressed and appeared to be".

The statement that appearance influences job interviews, increasing the chances of hiring, confirms what Rooth (2009) and Santos (2016) propose. Following its theories, I3 added:

The interviewer may think this, at that time, he/she may see this as a slopiness, as a lack of concern, since this is also a point in the recruitment evaluation, and it adds points. In a job interview, things are more radical; you have to be adequate to earn points. In that story, we must use our appearance as our advantage in all situations (I3).

Properly, 13 stated that, sometimes, she is afraid to talk about appearance because, depending on how it is interpreted, it may seem that it is futile, "and appearance is not futile, we live on it, live with it, we show ourselves to people through our appearance [...] appearance is not just clothes". The relevance that the interviewees attributed to their appearance at the time of the interview also reinforces the theories of Sorcher and Brant (2002), Wilson and Eckel (2006), and Kahneman (2011) about the influence of the halo effect in job interviews, when first impressions influence people's judgment. Perhaps this concern becomes eminent since physical and aesthetic criteria may mark labor relationships, which do not necessarily involve the qualification of this professional (ESTEVÃO-REZENDE, NASCIMENTO; ALVES, 2018).

Regarding the promotion of professionals, 12 stated that she takes into account the issue of appearance: "You can be very competent, have the best technical knowledge if you don't dress appropriately in the company, you may even remain there because you are very good, but you won't get a promotion, you won't earn a higher salary, you won't move forward." This thinking can encourage a consumption focused on the body and appearance because it is a way for this professional to become as visible and valuable as any other employee who would be eligible for promotion (GORDON, 2019).

14 and 15 agreed that in operational areas, appearance does not have the same relevance: "In the operational area, I don't think so, because the operational does not visit customers and suppliers. Usually, many are still university students in the operational area, as I was one. So we don't have that concern". This point of view is consistent with the theory of Sierminska (2015), which proposes that appearance is more relevant in occupations that require interaction between employee and customer.

\section{FINAL CONSIDERATIONS}

This research points to some relevant findings on the contribution of appearance to women in the labor market, from a class council executive women's perspective, in southern Brazil. Among the contributions 
of this research, the following stood out: a good appearance can boost careers because it not only makes people more confident, but it tells about the degree of willingness of a professional. Appearance also contributes to providing greater credibility to people in the labor market, bringing them closer to their professional goals. The different business areas of the interviews come together through the Council of Businesswoman, where they practice common interests. The counselors reported entrepreneurship stories in their careers, about the need to prove their worth as professionals and the development of their technical skills to gain a prestigious labor market position.

Even for women who seem to have an established professional destiny, as is the case of those who inherit family businesses, the need to demonstrate their skills is a reality, mainly because the expectation in the business world is still higher for women than it is for men, even in the highest hierarchical levels. The differentiation between men and women in the labor market was confirmed by the interviewees' reports, who also recognize the existence of predominantly male fields. Such fields still differentiate women, as is civil construction, metallurgy, and IT companies. Even if it is not discriminatory, some areas still differentiate women, perpetuating a segregated labor market. Wage differences and the reduced number of women in business are examples of this. To break down these barriers in the business world, women need to stand out even more than men in terms of their ability, highlight their skills and competencies, and take care of their appearance.

Regarding the understanding of appearance in the professional sphere, appearance was considered an essential factor, analyzed under different aspects. Adequacy proved to be a central factor in determining what characterizes a good appearance, even more for a person in the market who wishes to rise. It is a matter of knowing the market in which you intend to operate, of the customers you intend to reach, of communication in each area. However, there seems to be an established pattern about successful women, which, besides adequacy, is also linked to elegance.

Another aspect of the appearance that proved to be important is dressing. Besides adapting to the environment, dressing is related to the cleanliness, size, and discretion of clothes. Anything exaggerated distracts the listener and diminishes the women's speech credibility, making their communication much more difficult in the labor market. The consequence is that the goals may not be achieved or possibly take more time to be achieved. The appearance was also related to the tone of voice, which must be soft and related to elegance. Communication, which is also part of the appearance, must be formal in the labor market.

Aesthetic care is also a factor in people's appearance, even more significant in business activities where there is interaction with customers and suppliers and in frontline positions of the companies, where the person's image is also the image of the company. This association between the image of the company and the image of its employees and managers occurs. There seems to be a standardization between the company profile and the employee profile, a filter performed at the interview moment. This research also revealed that appearance interferes in promoting professionals and is considered for promoting employees, even though it does not overlap the person's technical capabilities.

It is often necessary for a specific event to occur in women's lives to recognize the value of a good appearance. However, there is no need to wait for that to happen. If the stereotype of a successful woman is elegance, why not trying to approach that stereotype? Appearance is not just a beautiful outfit. It is our communication with the world, and it tells us about who we are and where we intend to go. Appearance can also favor a candidate in a job interview. It means the first impression is decisive in the hiring processes. It is an occasion when the halo effect manifests, and the candidate must be careful not to let the appearance sabotage her since a bad appearance can stand out over the person's skills when the first impression is crucial.

In addition to the academic contribution, from the point of view of management, this research can serve as a guide to support women inserted in the labor market. Its results can help women obtain better remuneration, win more representative positions, and increase the chances of hiring in selection processes, which includes the search for new opportunities and professional replacement. The research results confirm that a pleasant appearance acts as a propellant in these situations and that the business environment responds, in a pleasant way, to an attractive personal image. Good looks and fitness are essential assistants in building successful careers. Companies value those who look good and are concerned with adapting 
themselves to their profile. It is an effort that does not go unnoticed and does not require significant investments. However, everything indicates that investments will return in the form of greater professional recognition.

Despite the merits of this research, as discussed above, the study has limitations. It is noteworthy that the interviewees were women who, upon receiving the proposal to participate in this research at a meeting of the Council of Businesswoman and having prior knowledge of the topic that would be addressed, were willing to participate in the interview. Perhaps women who are not so concerned about appearance have not shown interest in the research. However, it is worth mentioning that some interviewees commented that all women on the Council are references in terms of appearance and adequacy. That said, another limitation of the research resides in delimiting to women who act as counselors in a class entity and, also, to the fact of having considered only the opinion of women. Additionally, the use of different terms referring to the appearance by the authors and the interviewees, sometimes treated as appearance, sometimes treated by other terms, such as image, personal image, and beauty, is also a limitation.

As suggestions for future research, it is proposed to research the same topic outside a class entity, with women from other hierarchical levels, or according to men's perspective, since there are authors who do not differentiate gender when referring to the appearance in the labor market. Quantitative research on the topic is also suggested, with a larger sample of people, to identify relationships between investment in appearance and positions held, or investment in appearance and salaries received. Finally, we suggest analyzing the issue of predilection for the male figure in administrative areas and the issue of differentiation between men and women, highlighted by the interviewees, in other positions and specific areas.

\section{REFERENCES}

ABIHPEC. Associação Brasileira da Indústria de Higiene Pessoal, Perfumaria e Cosméticos. Panorama do setor. 2017. Disponível em: https://abihpec.org.br/publicacao/panorama-do-setor-2017. Acesso em: 30 out 2019.

ANDREONI, James; PETRIE, Ragan. Beauty, gender and stereotypes: Evidence from laboratory experiments. Journal of Economic Psychology, v. 29, n. 1, p. 73-93, 2008. DOl: https://doi.org/10.1016/j.joep.2007.07.008

BARDIN, L. Analyse De Contenu. Paris: Presses Universitaires de France, 2013.

BARROS NETO, J. P. Liderança: entre o poder e a liberdade nas organizações modernas. Revista Estudos em Liderança, v.7, p. 21-30, 2005.

BENCKE, Fernando Fantoni. A experiência gaúcha de parques científicos e tecnológicos à luz da tríplice hélice. 2016. 349 f. Tese (Doutorado) - Universidade de Caxias do Sul, Programa de Pós-Graduação em Administração da Universidade de Caxias do Sul, 2016.

BETIOL, Maria Irene Stocco; TONELLI, Maria José. A mulher executiva e suas relações de trabalho. Revista de Administração de Empresas, v. 31, n. 4, p. 17-33, 1991. DOl: https://doi.org/10.1590/S003475901991000400003

BIDDLE, Jeff E.; HAMERMESH, Daniel S. Beauty, productivity, and discrimination: Lawyers' looks and lucre. Journal of labor Economics, v. 16, n. 1, p. 172-201, 1998. DOl: https://doi.org/10.1086/209886

BÓO, Florencia López; ROSSI, Martín A.; URZÚA, Sergio S. The labor market return to an attractive face: Evidence from a field experiment. Economics Letters, v. 118, n. 1, p. 170-172, 2013. DOI:

https://doi.org/10.1016/j.econlet.2012.10.016 
BOURDIEU, Pierre. Masculine domination. Stanford University Press, 2001.

BRUSCHINI, Cristina; LOMBARDI, Maria Rosa. Instruídas e trabalhadeiras Trabalho feminino no final do século XX. Cadernos Pagu, n. 17-18, p. 157-196, 2002. DOI: https://doi.org/10.1590/S0104-83332002000100007.

BRUSCHINI, Maria Cristina Aranha. Trabalho e gênero no Brasil nos últimos dez anos. Cadernos de Pesquisa, v. 37, n. 132, p. 537-572, 2007. DOI: https://doi.org/10.1590/S0100-15742007000300003.

CALIL, L. E. S. História do direito do trabalho da mulher: aspectos históricos-sociológicos do início da república ao final deste século. São Paulo: LTr., 2000.

CIC. Câmara de Indústria, Comércio e Serviços de Caxias do Sul. Apresentação. 2018. Disponível em: http://ciccaxias.org.br/cic/. Acesso em: 25 mar. 2021.

COUNCIL OF BUSINESSWOMAN OF CIC. 20 Anos Pelo Empreender Feminino. Caxias do Sul, RS: CIC/RS, 2017.

COSTA, L. B. A participação da mulher no mercado de trabalho. São Paulo: IPE-USP, 1984.

DENZIN, N.; LINCOLN, Y. The Sage Handbook of Qualitative Research. Thousand Oaks, California: SAGE Publications, 2018.

DUBAY, T. The evidential power of beauty. San Francisco: Ignatius, 1999.

DWECK, Ruth Helena. A beleza e o mercado de trabalho: uma perspectiva de gênero. Revista Gênero, v. 7, n. $1,2006$.

DZUBINSKI, Leanne; DIEHL, Amy; TAYLOR, Michelle. Women's ways of leading: The environmental effect. Gender in Management: An International Journal, v. 34, n. 3, p. 233-250, 2019. DOI: https://doi.org/10.1108/GM-11-2017-0150.

FEDERASUL. CIC 115 anos: uma trajetória pelo desenvolvimento de Caxias do Sul. 2016. Disponível em: http://www.federasul.com.br/cic-115-anos-uma-trajetoria-pelo-desenvolvimento-de-caxias-do-sul. Acesso em: 30 out. 2019.

FERNANDES, Maria Neyrian de Fátima et al. Assédio, sexismo e desigualdade de gênero no ambiente de trabalho. Revista Eletrônica da Faculdade de Direito de Franca, v. 14, n. 1, p. 237-253, 2019. DOI: https://doi.org/10.21207/1983.4225.615.

ESTEVÃO-REZENDE, Yuri Alexandre; NASCIMENTO, Sarah Christina; ALVES, Kerley dos Santos. "Você não tem o perfil dessa vaga": padrões de beleza, gênero e relações de trabalho. CSOnline-Revista Eletrônica de Ciências Sociais, n. 27, 2018. DOI: https://doi.org/10.34019/1981-2140.2018.17540.

FLICK, U. The sage handbook of qualitative data collection. London: SAGE Publications, 2018a.

FLICK, U. Managing quality in qualitative research. London: Bookman, 2018b. 
FRIEZE, Irene Hanson; OLSON, Josephine E.; RUSSELL, June. Attractiveness and income for men and women in management 1. Journal of Applied Social Psychology, v. 21, n. 13, p. 1039-1057, 1991. DOI: https://doi.org/10.1111/j.1559-1816.1991.tb00458.x

GIPSON, Asha N. et al. Women and leadership: Selection, development, leadership style, and performance. The Journal of Applied Behavioral Science, v. 53, n. 1, p. 32-65, 2017. DOI: https://doi.org/10.1177/0021886316687247.

GOMES, Juliana Penha. Beleza e carreira no Brasil: O significado da beleza para jovens executivas e seu papel no mercado de trabalho. 2010. 87 f. Dissertação (Mestrado) - Fundação Getúlio Vargas, Escola de Administração de Empresas de São Paulo, 2010.

GORDON, Doreen. Body Beautiful: Comparative Meanings of Beauty in Brazil, South Africa and Jamaica. In: Beauty and the Norm. Palgrave Macmillan, Cham, 2019. p. 215-244. DOI: https://doi.org/10.1007/978-3-31991174-8_10.

GRAHAM, John R.; HARVEY, Campbell R.; PURI, Manju. A corporate beauty contest. Management Science, v. 63, n. 9, p. 3044-3056, 2017. DOI: https://doi.org/10.1287/mnsc.2016.2484

GRZYBOVSKI, Denize; BOSCARIN, Roberta; MIGOTT, Ana Maria Bellani. Estilo feminino de gestão em empresas familiares gaúchas. Revista de Administração Contemporânea, v. 6, n. 2, p. 185-207, 2002. DOI: https://doi.org/10.1590/S1415-65552002000200011

HABERMANN-HORSTMEIER, Lotte. Restriktives Essverhalten bei Frauen in Führungspositionen. Ein gesundheitlicher Risikofaktor, p. 326-337, 2007.

HAKIM, C. Honey money: the power of erotic capital. London: Allen Lane, 2011.

HAMERMESH, D. Beauty pays: why attractive people are more successful. Princeton: Princeton University Press, 2011.

HEWLETT, S. A. Executive presence: the missing link between merit and success. New York: Harper Collins, 2014.

IBGE. Instituto Brasileiro de Geografia e Estatística. Pesquisa Nacional por Amostra de Domicílios Contínua Trimestral. 2017. Disponível em: https://sidra.ibge.gov.br/tabela/5436. Acesso em: 30 out. 2019.

ISRAELSSON, Jennifer Lezis. Sexism and gender equality at trade shows. Diva, Halmstad, jan. 2017. Disponível em: http://urn.kb.se/resolve?urn=urn:nbn:se:hh:diva-33071. Acesso em: 30 out. 2019.

KAHNEMAN, D. Thinking fast and slow. New York: Farrar, Straus and Giroux, 2011.

KURY, L.; HARGREAVES, L.; VALENÇA, M. (2000). Ritos do corpo. Rio de Janeiro: Senac Nacional, 2000.

LEONE, Eugenia; BALTAR, Paulo. Mercado de trabalho metropolitano: gênero e diferenças de rendimento.

Revista Brasileira de Estudos de População, São Paulo, v. 23, n. 2, p. 335-367, jul./dez. 2006. DOI: https://doi.org/10.22409/rg.v7i1.345 
$Ł O P A C I U K$, Aleksandra; ŁOBODA, Mirosław. Global beauty industry trends in the 21st century. In: Management, Knowledge and Learning International Conference. 2013. p. 19-21. Disponível em: http://www.toknowpress.net/ISBN/978-961-6914-02-4/papers/ML13-365.pdf. Acesso em: 30 out. 2019.

MAHAJAN, Ritu. The naked truth: Appearance discrimination, employment, and the law. Asian Am. LJ, v. 14, p. 165, 2007. DOI: https://doi.org/10.15779/Z385P3K

MARWICK, A. A history of human beauty. London: A\&C Black, 2004.

MOBIUS, Markus M.; ROSENBLAT, Tanya S. Why beauty matters. American Economic Review, v. 96, n. 1, p. 222-235, 2006. Disponível em: https://www.jstor.org/stable/30034362. Acesso em: 30 out. 2019.

NOGUEIRA, C. M. A feminização no mundo do trabalho: entre a emancipação e a precarização. Campinas: Autores Associados, 2004.

PERCY, William H.; KOSTERE, Kim; KOSTERE, Sandra. Generic qualitative research in psychology. The Qualitative Report, v. 20, n. 2, p. 76-85, 2015. Disponível em: http://citeseerx.ist.psu.edu/viewdoc/download?doi=10.1.1.674.8560\&rep=rep1\&type=pdf. Acesso em: 30 out. 2019.

RAMOS, C. A. Economia do trabalho: modelos teóricos e o debate no Brasil. Curitiba: CRV, 2012.

ROCHA-COUTINHO, Maria Lúcia. Novas opções, antigos dilemas: mulher, família, carreira e relacionamento no Brasil. Temas em Psicologia, v. 12, n. 1, p. 02-17, 2004.

ROQUE, Camila Bertoleto; BERTOLIN, Patrícia Tuma Martins. As carreiras das mulheres no Brasil: igualdade de oportunidades ou teto de vidro?. Brazilian Journal of Development, v. 7, n. 3, p. 23792-23813, 2021. DOI: https://doi.org/10.34117/bjdv7n3-202.

ROOTH, Dan-Olof. Obesity, attractiveness, and differential treatment in hiring a field experiment. Journal of human resources, v. 44, n. 3, p. 710-735, 2009. DOl: https://doi.org/10.3368 / jhr.44.3.710

SANT'ANNA, D. B. História da beleza no Brasil. São Paulo: Contexto, 2014.

SANTOS, B. M. P. R. S. Planejamento pessoal, para melhorar aparência, na hora da seleção para uma vaga emprego. Revista de Administração e Comércio Exterior, v. 2, n. 2, p. 36-52, 2016.

SCHNEIDER, F.; GRUMAN, J.; COUTTS, L. Applied social psychology: understanding and addressing social and practical problems. 2. ed. Thousand Oaks: Sage Publications Inc., 2012.

SIERMINSKA, E. Does it pay to be beautiful? IZA World of Labor, p. 161-171, 2015. DOI: https://doi.org/10.15185 / izawol.161

SORCHER, Melvin; BRANT, James. Are you picking the right leaders?. Harvard Business Review, v. 80, n. 2, p. 78-87, 2002.

SOUSA, Luana Passos de; GUEDES, Dyeggo Rocha. A desigual divisão sexual do trabalho: um olhar sobre a última década. Estudos Avançados, v. 30, n. 87, p. 123-139, 2016. DOI: https://doi.org/10.1590/S010340142016.30870008 
STANDING, L. Halo Effect. Thousand Oaks: SAGE Publications, 2004.

TALAMAS, Sean N.; MAVOR, Kenneth I.; PERRETT, David I. Blinded by beauty: Attractiveness bias and accurate perceptions of academic performance. PloS one, v. 11, n. 2, p. e0148284, 2016. DOI:

https://doi.org/10.1371/journal.pone.0148284

THORNDIKE, Edward L. A constant error in psychological ratings. Journal of applied psychology, v. 4, n. 1, p. 25-29, 1920. Disponível em: https://psycnet.apa.org/fulltext/1920-10104-014.pdf. Acesso em: 30 out. 2019.

WILSON, Rick K.; ECKEL, Catherine C. Judging a book by its cover: Beauty and expectations in the trust game. Political Research Quarterly, v. 59, n. 2, p. 189-202, 2006. DOI:

https://doi.org/10.1177/106591290605900202

WONG, Jaclyn S.; PENNER, Andrew M. Gender and the returns to attractiveness. Research in Social Stratification and Mobility, v. 44, p. 113-123, 2016. DOI: https://doi.org/10.1016/j.rssm.2016.04.002

WORLD BANK. Women, Business, and the Law 2018. 2018. Washington, D.C.: World Bank Group. Disponível em: http://documents.worldbank.org/curated/en/926401524803880673/Women-Business-and-the-Law2018. Acesso em: 30 out. 2019. 